\title{
Soft Tissue Wound Healing by Laser
}

\author{
Mohammad Nazrul* \\ Department of Biotechnology, Shaheed Suhrawardy Medical College, Bangladesh
}

Submission: March 28, 2017; Published: August 23, 2017

*Corresponding author: Mohammad Nazrul, Department of Biotechnology, Shaheed Suhrawardy Medical College, Bangladesh

Background

In 1967 a few years after the first working laser was invented, Endre Mester in Semmelweis University Budapest, Hungary wanted to find out if laser might cause cancer. He took some mice, shaved the hair off their backs, divided them into two groups and gave a laser treatment with a low powered ruby laser to one group. They did not get cancer and to his surprise the hair on the treated group grew back more quickly than the untreated group. That was how "laser biostimulation" effects were discovered. (Effect of laser on hair Growth of mice (in Hungarian). Mester E, Szende B and Tota, J (1967). Kiserl Orvostud 19. 628-631).

Keywords: Bedsore healing; Soft tissue healing; Decubitus ulcer; Ulcer healing; Wound healing; Low level laser; Laser therapy

\section{Purpose of the Work}

The effects of pulsed monochromatic light, with fixed pulsations and wavelengths, on the healing of pressure ulcers were evaluated in this prospective, randomized, controlled study.

\section{Method}

A placebo-controlled, double-blind study using low energy photon therapy (LLLT) was performed in ten patients with bedsore on the back. Treatment was given three times a week for 10 weeks, using monochromatic (red) optical sources; diode 660nm (GaAl-660). The patients who were randomized to placebo treatment received sham therapy from an identicalappearing light source from the same delivery system.

\section{Results}

Ten patients with bedsore were randomized to receive LLLT or placebo therapy. At the conclusion of the study, the percentage of the initial ulcer area remaining unhealed in the LLLT and placebo groups was $24.4 \%$ and $84.7 \%$, respectively ( $\mathrm{P}=0.0008$ ). The decrease in ulcer area (compared to baseline) observed in the LLLT and placebo groups was $193.0 \mathrm{~mm} 2$ and $14.7 \mathrm{~mm} 2$, respectively ( $\mathrm{P}=0.0002)$. One patient dropped out of the study, complaining of lack of treatment efficacy; he was found to be randomized to the placebo group. There were no adverse effects.

\section{Conclusion}

In this placebo-controlled, double-blind study LLLT was an effective modality for the treatment of bedsore which were resistant to conventional medical management. The results are encouraging as pulsed monochromatic light increased healing rate and shortened healing time. This will positively affect the quality of life in elderly patients with pressure ulcers (Figure 1-10).

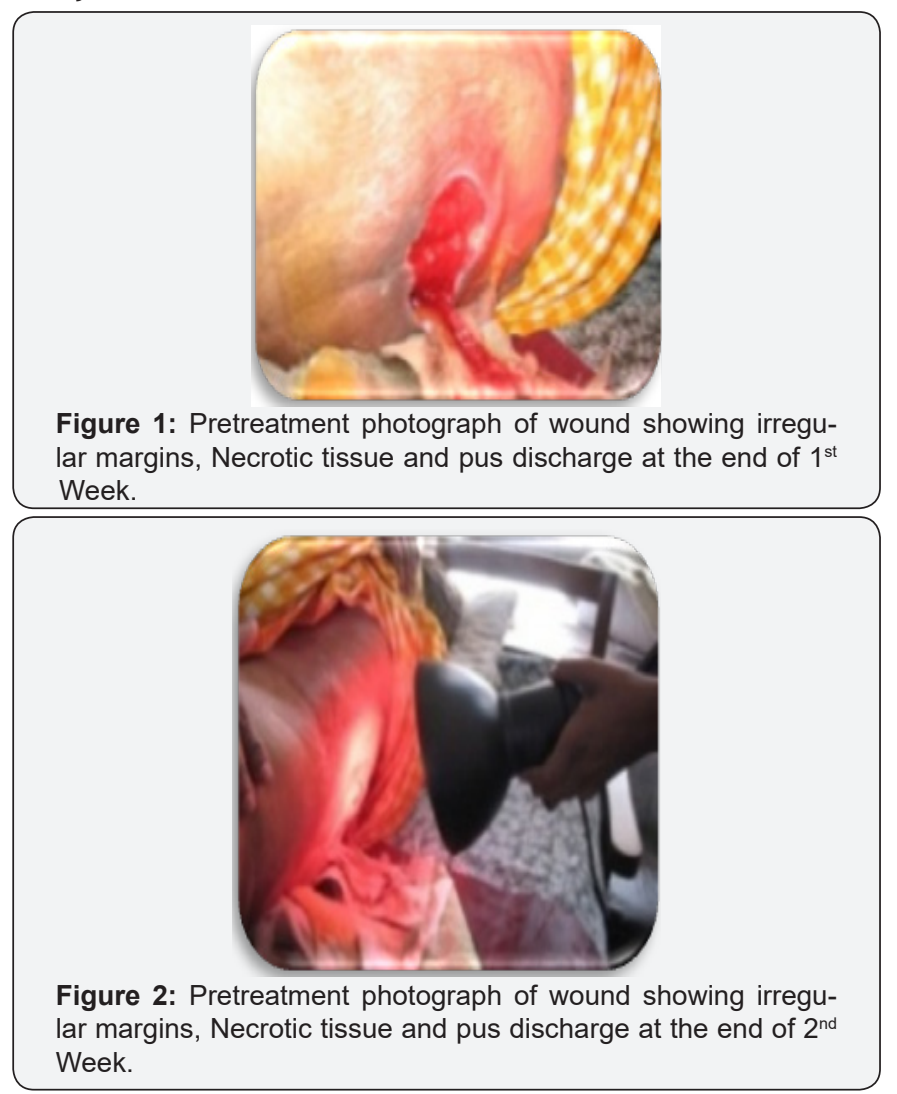




\section{Current Trends in Biomedical Engineering \& Biosciences}

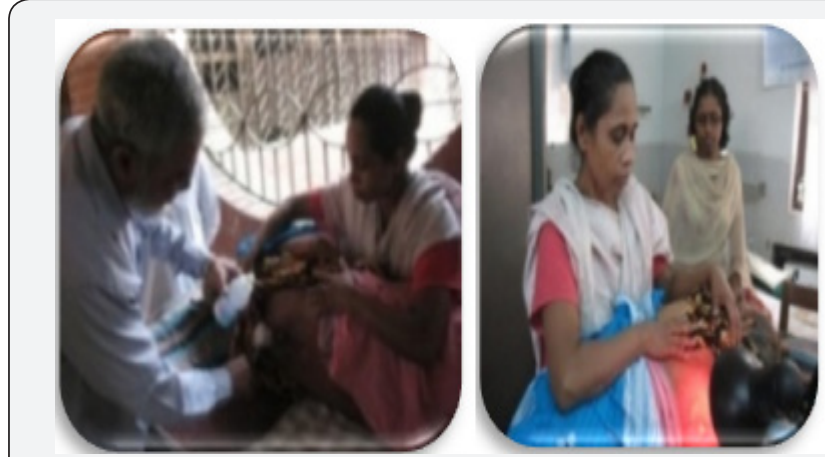

Figure 3: Pretreatment photograph of wound showing irregular margins, Necrotic tissue and pus discharge at the end of $3^{\text {rd }}$ Week.

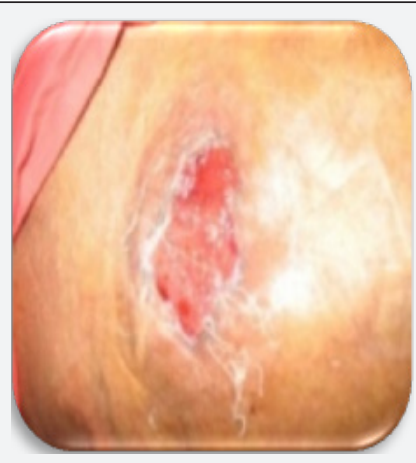

Figure 4: Pretreatment photograph of wound showing irregular margins, Necrotic tissue and pus discharge at the end of $4^{\text {th }}$ Week.

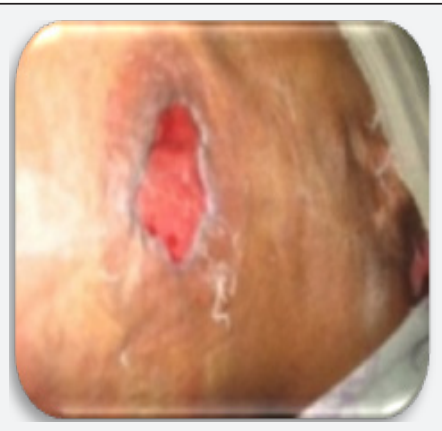

Figure 5: Pretreatment photograph of wound showing irregular margins, Necrotic tissue and pus discharge at the end of $5^{\text {th }}$ Week.

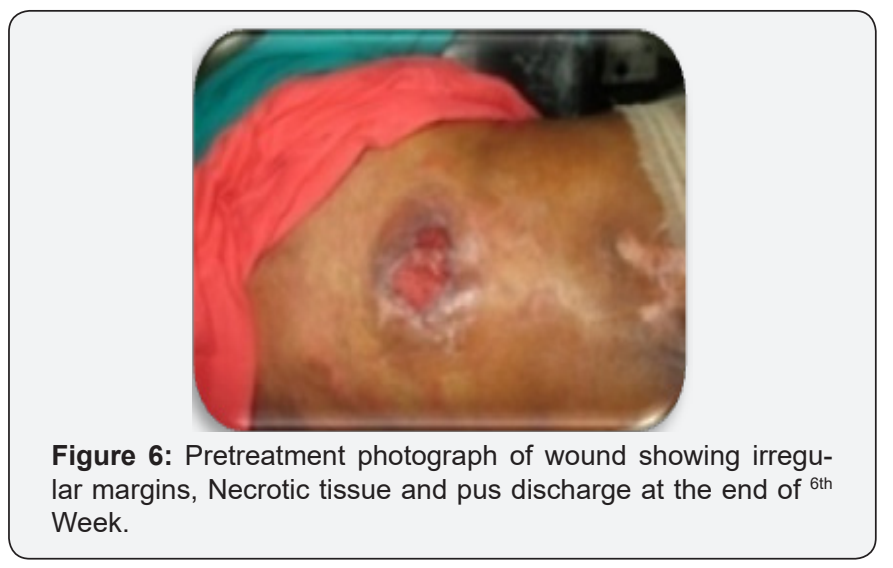

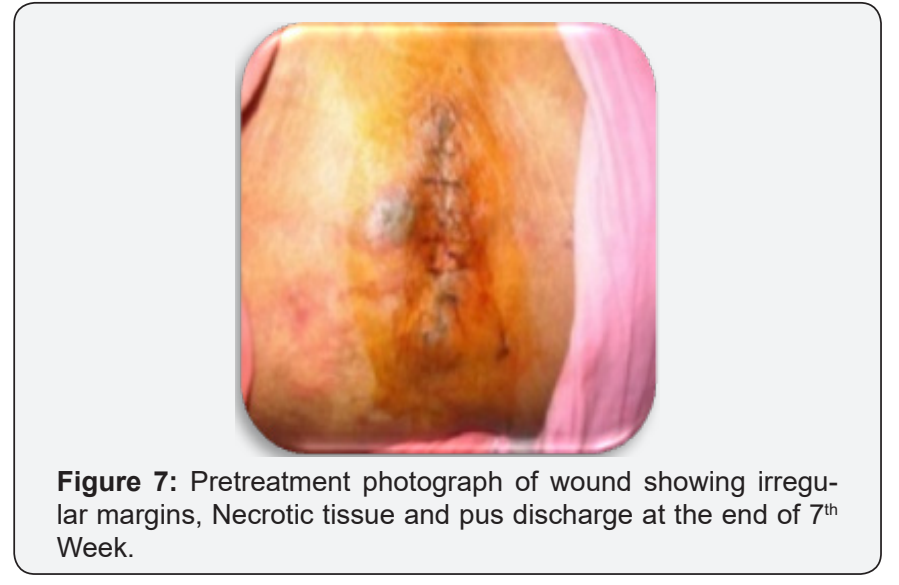
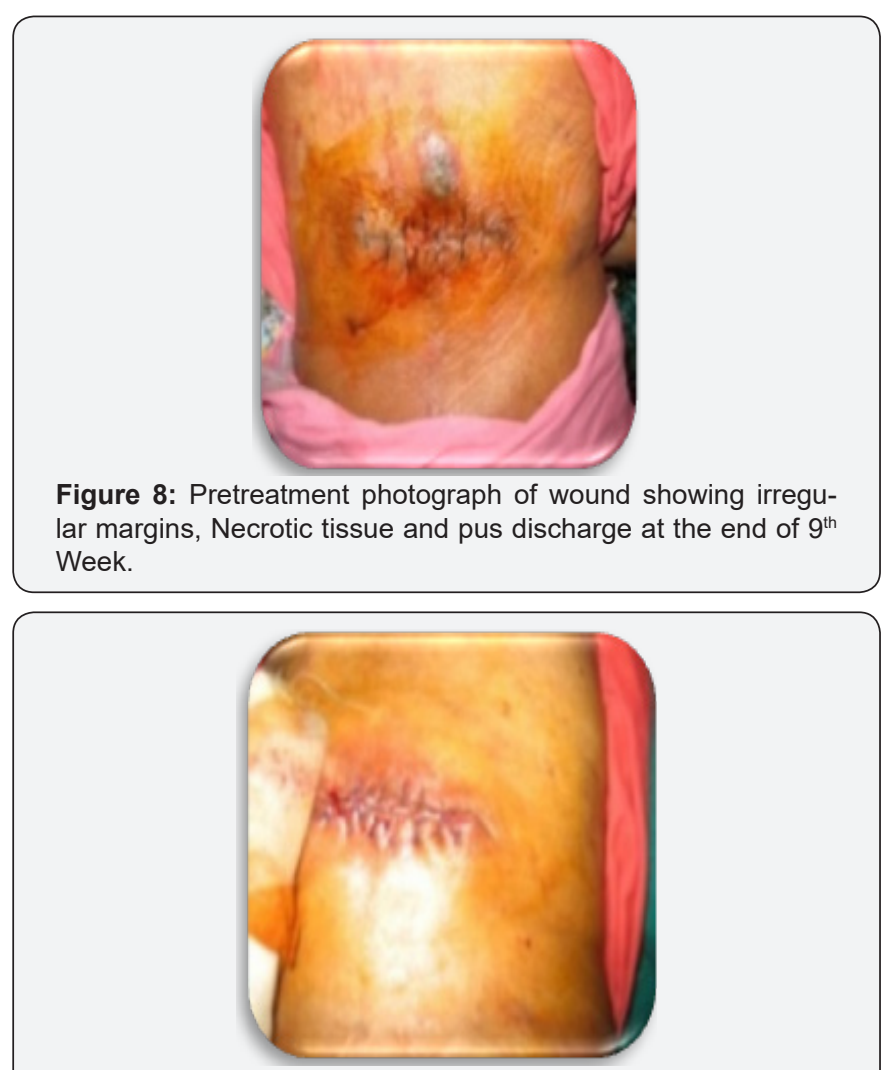

Figure 9: Pretreatment photograph of wound showing irregular margins, Necrotic tissue and pus discharge at the $10^{\text {th }}$ Week.

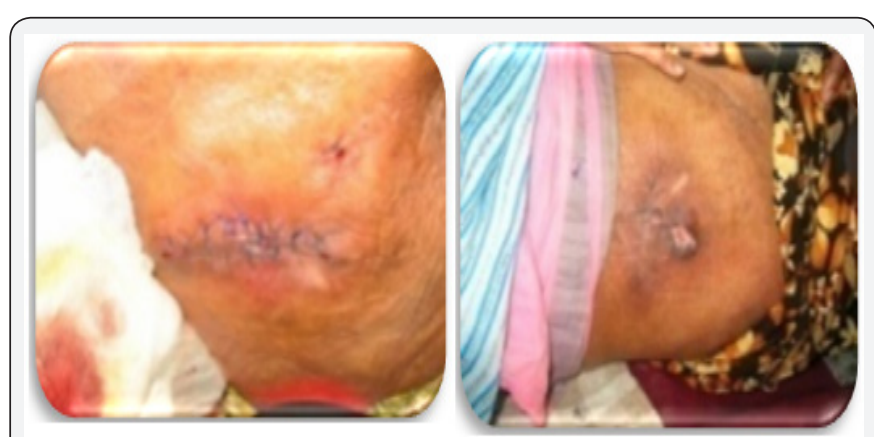

Figure 10: Pretreatment photograph of wound showing irregular margins, Necrotic tissue and pus discharge at the end of $10^{\text {th }}$ Week. 
This work is licensed under Creative Commons Attribution 4.0 License DOI:_10.19080/CTBEB.2017.07.555713
Your next submission with Juniper Publishers will reach you the below assets

- Quality Editorial service

- Swift Peer Review

- Reprints availability

- E-prints Service

- Manuscript Podcast for convenient understanding

- Global attainment for your research

- Manuscript accessibility in different formats ( Pdf, E-pub, Full Text, Audio)

- Unceasing customer service

Track the below URL for one-step submission https://juniperpublishers.com/online-submission.php 